\title{
MAN DOMINATION AND DOMESTIC VIOLENCE DESCRIBED IN SWEAT BY ZORA NEALE HURSTON
}

\author{
Yogi Ario Setiawan ${ }^{1}$, Agnes Widyaningrum² \\ Faculty of Language and Cultural Studies, Stikubank University \\ email: yogiariosetiawan@gmail.com ${ }^{1}$, agneswidyaningrum@edu.unisbank.ac.id ${ }^{2}$
}

\begin{abstract}
This study is a descriptive qualitative study, focused in discussing the domestic violence and man domination that are potrayed in Zora Neale Hurston "Sweat" in 1926. This story presents a woman who is trapped in a bad marriage. This story has protagonist character and antagonist character. The woman in this story is protagonist, and the man is antagonist. The woman becomes victim of domestic violence. She has to struggle to provide her living. As a part of feminism study, the researcher uses feminism approach. It focuses on the explanation on how the character gets violence using Simone de Beauvoir theory "The Second Sex" (1949) which is applied to analyze this research paper. The aim of this research is to analyze the problem of domestic violence towards woman. The researcher shows the domestic violence happened in that era, and men are dominant because of the social construct build to make men are powerful. Domestic violence and man domination in the early $20^{\text {th }}$ century can truly be seen in Zora Neale Hurston story.
\end{abstract}

Keywords: Domestic Violence, Man domination, Feminism, Sweat, The Second Sex

\section{INTRODUCTION}

Violence against women still becomes a crucial case that never ends, from sexual harassment to domestic violence. Feminist movements and the foundation of the women protection began to appear in harmony with many cases occurred, for example in married life, the violence against couples still occurred, that led to physical injuries, psychological disorders, and divorce. According to Arizona Coalition to End Sexual \& Domestic Violence, or abbreviated as ACESDV: "Domestic violence is not physical violence alone. Domestic violence is any behavior which power of control over a spouse, partner, girl or boyfriend or intimate family member". (It is accessed on October, 152018 from https://acesdv.org/domestic-violence-graphics/)

Based on actual data, more than one-third of women in the United States (35,6\% or approximately 42,4 million) have experienced rape, physical violence, and/or stalking by an intimate partner at some point in their lifetime. These data are taken according to a survey of NISVS, National Intimate Partner and Sexual Violence Survey (NISVS, 2010:39). Based on the data, more women become the victims. Such violent treatment can make the victim is unable to perform daily activities with calmly, because they imagine the fear.

Concerning to this conditions, some writers create works reflected on domestic violence and domination of men. Most of their works are the invitation to resist patriarchy 
which is not expressly stated though they made some points of their works implicitly but it is meaningfully against patriarchy. The storyline in the work of patriarchal put the female characters end tragically and sadly while the goal is to make the reader to open their heart and mind that women are still not in good condition.

Zora Neale Hurston, an American novelist known for her contributions to the AfricanAmerican literature. She wrote a short story entitled 'Sweat' which reflects the social conditions at that time where violence against women and racial acts still occur. This story was written in 1926. This story has nine pages which tells about domestic violence and male domination. Starting from Delia Jones who was trapped in a bad marriage. She is a washerwoman, who has worked for 15 years to fulfill the needs of her home. She is a woman who is gentle, obedient, and devout. In contrast to Sykes, her husband, is someone who is unemployed and abusive. He likes women with fat posture than skinny.

In her daily life, Delia Jones often gets bad treatment from her husband. Delia Jones's fear of snakes makes her husband enjoy playing with his wife's weakness. One day he threw his wife with a bull-whip who was instantly afraid because his wife thought it was a snake. Her husband laughed and was pleased to see that.

Delia Jones often gets both physical and verbal abuse. Until one night she prayed that her husband would not commit another act of violence. The neighbors already know the trait of Delia Jones's abusive husband, and the cruel treatment of his wife. Even Sykes was having an affair with another woman.

One day, Sykes brought a rattle snake and brought it home. His wife who knew this, fear and did not dare to sleep in the house and decided to sleep in the barn. The next day a man's voice came from the house asking for help. His wife came to the house and peered out the window, it was Sykes's voice asking for help because he had just been bitten by his own snake. Delia Jones who knew this, dared not to help her husband and chose not to do anything.

\section{LITERATURE REVIEW}

At this time, or have been since a long time ago, women have received unequal treatment by men in society. The social systems, and even a culture says that men are superior. Based on that situation, it caused protests from women, and the feminist movement had been started. Definition of feminist movement and ideologies demands equality to woman. The goal is to achieve social equality of sexes. According to Judith Lorber, The main 
point feminists have stressed about gender inequality is that it is not an individual matter, but is deeply ingrained in the structure of societies. Gender inequality is built into the organization of marriage and families, work and the economy, politics, religions, the arts and other cultural productions, and the very language we speak. (1997:8)

\subsection{The Second Sex}

The Second Sex is the famous of De Beauvoir work. It contains protest about the patriarchal system in society. It was published in 1949, and became a major work of feminist philosophy. She wrote this book in 14 months, when she was 39 years old. This book has two volumes. Facts and Myths and Lived Experience. In this book, De Beauvoir considers woman as the "Other", means woman is inferior. In this book, she fought for equality of women's rights in the social system.

In this research, the researcher will analyze using Simone De Beauvoir theory from The Second Sex volume one Facts and Myths, "men have always held all the concrete powers; from patriarchy's earliest times they have deemed it useful to keep woman in a state of dependence."(2011:193). In other words, domestic violence was linked to power relations where the powerful in society (men) deny the powerless (women) any right and power because women are not in a position to challenge men as a result of cultural construction of masculinity and femininity: it emerged that women who attained higher status in education and are economically independent are the minority of victims of domestic violence. (Isaac Dery, 2014:232).

In short, man will use every ways to stay in a high position, even though he doesn't have the financial power. Women are not allowed to challenge man.

\subsection{Domestic Violence}

Domestic Violence is a case that is still common today. The trigger can be varied. According to Anne L. definition of domestic violence is a pattern of assaultive and coercive behaviors, including physical, sexual, and psychological attacks, as well as economic coercion, that adults or adolescents use against their intimate partners (1996:16). So the definition of domestic violence is an action which happens at home or in a neighborhood that can happen by the husband, wife, or child, which has a negative impact on mental health, physical, and harmony relationship. Domestic violence has several types, based on their actions. 


\subsection{Physical Abuse}

Physical abuse can either be controlled or impulsive and consists of physical assaults. These result in injuries ranging from bruising, scalding, burning and stabbing to internal injuries, cracked ribs or broken bones. Persistent blows to the head may cause serious head injuries that often go undetected and untreated. Physical abuse examples are spitting, scratching, biting, grabbing, shaking, shoving, pushing, restraining, throwing, twisting, slapping, punching, choking, burning, or use weapons to against the victim. The physical assaults may not cause injuries. Sometimes the physical abuse does not cause a specific injury but does cause health problems.

\subsection{Sexual Assaults}

Sexual abuse occurs when the perpetrator demands sexual acti ity without the woman's consent. Sexual violence can occur when a partner does not want to have sex, forced sex with threats, or physically forced sex. Victims can be forced to have sex with an unwanted sex partner. Having physically painful sex, verbal abuse during sex, etc. Some cases can occur with attacks on the victim's genitals with blows or weapons.

\subsection{Psychological Assaults}

A. Threats of Violence and Harms : Threats from perpetrators of violence can be directed against others who have a relationship with the victim. Threats can occur by killing other people who have an important relationship to the victim, which can trigger the victim to commit suicide. Threats can be verbal, such as, "I will kill you! Your mother will pay for it, no one will expect you to live!" Or it could be with actions such as holding hostage, displaying weapons, attempting suicide. Perpetrators can commit violence against others, for example with family members, or neighbors. The purpose is to terrorizing the victim.

B. Attacks against property or pets and other acts of intimidation : Attacks on property or pets can occur in cases of domestic violence. Perpetrators will damage property, such as plates, tables, chairs. Usually with property located around the offender. Or by threatening the victim's pet. Intimidation may not only damage property or pets, but can damage the victim's relationship with another person, bringing self-esteem in front of the victim's environment.

C. Emotional Abuse : Emotional abuse can be verbal or non-verbal. It is persistent and corrosive, destroying self-worth and self-esteem. This type of abuse usually includes the use of ridicule, insults, accusations, infidelity and ignoring one's partner, all of which result in the breaking down of the victim's self-esteem and self-worth. One type of defense consisting of insults and verbal attacks. It can occur with individuals, family members, the role of parents, 
coworkers, or friends. Emotional abuse can also occur in front of family or strangers. This threat has the aim of maintaining a dominant position.

D. Isolation : The perpetrator tries to control the victim through activities, time, and interactions with others. Perpetrators may lock the victim inside the house, or force the victim not to do in certain activities.

E. Use of Children : Perpetrators can use children to have control over their partners. By not supporting a child, or threatening to take the child from the victim, are some of the ways in which the victim remains compliant with the offender.

\subsection{Use Of Economics}

Perpetrators can control victims by controlling access to family resources such as transportation, food, time, clothing, insurance, money, and residence. Regardless of who provides the resources, the authorities regulate how finances are spent. economic abuse varies from irresponsible behaviour such as squandering money on chemical substances to refusing to contribute financially to the living expenses. There often is a false perception that women are solely responsible for the housekeeping, child-rearing and have to be the breadwinner, which exposes them to economic abuse

( Types of domestic violence above is taken from "Improving the Health Care Respone to Domestic Violence : A Resource Manual for Health Care Providers”, pages; 16-21)

\section{METHOD RESEARCH}

This research is a feminism study. The researcher focuses to analyze the character and collecting the data using qualitative methods. The data are taken from Sweat short story by Zora Neale Hurston about domestic violence. The researcher read the story and tried to understand the content and entire story, then collected the data about the domestic violence and man domination. The purpose of collecting data is to get many information about feminism and to support the process to accomplish the research. The data be analyzed using the theory on The Second Sex by Simone de Beauvoir.

\section{RESULT AND DISCUSSION}

\section{Why do man domination and domestic violence toward woman happen in Zora's Sweat?}

Sykes is abusive husband. He often does violence to his wife, Delia, for some reasons. He wants to goad his wife out of the house, and living with his girlfriend, Bertha. According 
to Alberta Human Services, the definition of abuse in intimate relationships is a pattern of behavior where one partner dominates, belittles or humiliates the other over months and years.

The way Sykes to make Delia chase away is treating violence, physically and psychologically. The purpose is to make Delia cannot stand with him and leave home. So, Sykes and his girlfriend, Bertha, can live together. It can be seen in the citation below.

Sho' you kin have datlil' ole house soon's Ah kin gitdat 'oman outa dere. Everything b'longstuh me an' you sho' kin have it. Ah sho' 'bominates uh skinny 'oman.Lawdy, you sho' is got one portly shape on you! You kin git anything you wants. Dis is mah town an' you sho' kin have it. (Sweat:1026)

The citation above is the part of conversation between Sykes and his girlfriend, Bertha. It can be seen that Sykes behavior is arrogant, "You kin git anything you wants. Dis is mah town an' you sho' kin have it”.

Besides, the way he sees woman is based on her shape. Another reason why Sykes does violence to his wife is because she is not his type physically. He hates thin woman. It can be proven based on the citation above "Ah sho' 'bominates uh skinny 'oman". It is not just one time he said Delia is skinny abusively. Another time, he said he hates thin woman in front of her brutally. It can be proven from citation below.

Well, you better quit gittin' me riled up, else they'll be totin' you out sooner than you expect. Ah'm so tired of you Ah don't know whut to do. Gawd! How Ah hates skinny wimmen! (Sweat:1023)

Different from Bertha, she has fat body, white people, and she is rich. She teaches him how to run automobile. It can be seen in the citation below conveyed by Jim Merchant and Old Man Anderson.

Aw, she's fat, thass how come. He's allus been crazy 'bout fat women (Sweat: 1024) We oughter take Syke an' dat stray 'oman uh his'n down in Lake Howell swamp an' lay on de rawhide till they cain't say Lawd a' mussy. He alluswuz uh ovah bearin' niggah, but since dat white 'oman from up north done teached 'im how to run a automobile, he done got too biggity to live---an' we oughter kill 'im.(Sweat:1025)

Another reason why he hates his wife is she works as washer of clothes for white people. In that time period, racial behavior is still exists. That is why, Sykes hates his wife's job. It can be seen in the citation below.

Ah done tole you time and again to keep them white folks' clothes outa dis house (Sweat:1022)

But Delia never responds, no matter what, even her husband disagreed with it. She just hates him because he is unemployed. She has to do this job to survive, and she had paid the house from her job as a washer people clothes. There is no other choice. 
What's it got to do with you, Sykes? Mah tub of suds is filled yo' belly with vittles more times than yo' hands is filled it. Mah sweat is done paid for this house and Ah reckon Ah kin keep on sweatin' in it. (Sweat:1023)

In the first citation it can be seen that Sykes is jobless. He never contributed for living cost. He is lazy, and Delia did everything. But Sykes still does abuse to her, to make her always in subordinate position. Women who are employed are nonetheless at the risk of domestic violence when their husbands are unemployed. This is the way Sykes to keeps his dominant position.

The plan to make his wife leaves the house is not going too easy. Delia loves the house so much. She paid the house already. It can be seen in the two citations below.

that ole snaggle-toothed black woman you runnin' with aintcomin' heah to pile up on mah sweat and blood. You aint paid for nothin' on this place, and Ah'mgointer stay right heah till Ah'mtoted out foot foremost. (Sweat:1023)

Yo' ole black hide don't look laknothin' tuh me, but uh passle uh wrinkled up rubber, widyo' big ole yeahsflappin' on each side lak uh paih uh buzzard wings. Don't think Ah 'mgointuh be run 'way fummah house neither. Ah'mgoin' tuh de white folks about you, mah young man, de very nex' time you lay yo' han's on me. (Sweat:1028)

According to the second citation above "Don't think Ah'mgointuh be run 'way fummah house nether", it means she will not leave the house, no matter what. It is hard for Sykes to set his wife away from the house, the only way to chase her is does abuse to her in physically and psychologically. Those are the reason why domestic violence and man domination happened in Sweat.

\section{How do man domination and domestic violence occur?}

In this chapter, the researcher analyzed the domestic violence which happened in Sweat. Domestic violence through woman happened because the man has dominant position in the patriarchy society. Woman cannot speak, or afraid to strike back even she has got violence from her husband.

When Delia sorted the clothes, Sykes is coming by bringing bull whip. This thing is used to make fun, using Delia sense fear of snake. After that, he throws right over her. Delia was scared! She thought it was snake. A real snake.

According to Alberta Human Services, there are two kinds of abuse tactics, the first one is Sexual Abuse Tactics, and the second one is Intimidation Tactics. The example of Sexual Abuse Tactics are uses force to get his partner to have sex in a way she does not want. Intimidation Tactics are any words or actions the abusive partner uses to scare her partner. 
Based on what Sykes doing to his wife, he gives Intimidation Tactics, because he scared her with things like snake. He deliberately did this to make Delia always feels in danger. The purpose is to make Delia can't stand at home.

Sykes, what you throw dat whip on me like dat? You know it would skeer me-looks just like a snake, an' you knows how skeered Ah is of snakes

Course Ah knowed it! That's how come Ah done it. (Sweat:1022)

Sykes used psychological violence to scare her. Of course, violence can be done in

several ways, such as psychological, physical, verbal, and so on. The purpose is to make the victims feel unsafe.

After Delia got scared by bull whip, she gets another repressive habitual. He knows his wife washing white people clothes ,then Sykes kicks all the clothes, because he hates it.

She saw that Sykes had kicked all of the clothes together again, and now stood in her way truculently, his whole manner hoping, praying, for an argument. But she walked calmly around him and commenced to re-sort the things. (Sweat:1022)

It is not just the first time he did this. He did this twice, kicking the clothes.

He stepped roughly upon the whitest pile of things, kicking them helter-skelter as he crossed the room. His wife gave a little scream of dismay, and quickly gathered them together again (Sweat:1023)

This story happened around 1920's, where America still had racial problems between white and black races. Based on these reasons, Sykes hates white people. He hates his wife jobs. Sykes never cares about his wife, even what she is doing, even she is doing it for their survive. He only wants to know everything should become what he wants. And for the first time, Delia responds what her husband did, and it is surprised him, because usually she never responds.

She seized the iron skillet from the stove and struck a defensive pose, ehich act surprised him greatly, coming from her. It cowed him and he did not strike her as he usually did. (Sweat:1023)

In the citation above "It cowed him and he did not strike her as he usually did", it can be the proven that he always abusive to her. Sykes did this from very long time. They are married for fifteen years. And she has got abusive for almost fifteen years. It can be proven from citation below.

Two months after the wedding, he had given her the first brutal beating. (Sweat:1023) Delia has got kinds of violence from her husband. based in the citation above, she got physical violence from him. Sykes hates Delia since day one.

The conflict is not just coming from Sykes. She also got internal conflict. Delia gives up, the situation cannot be back to normal, in harmony. It's too late. Delia didn't know what she is supposed to do. 
Too late now to hope for love, even if it were not Bertha it would be someone else. This case differed from the others only in that she was bolder than the others. Too late for everything except her little home. She had built it for her old days, and planted one by one the trees and flowers there. It was lovely to her, lovely. (Sweat:1024)

The house is the reason why Delia keeps standing. The house is her final hope, because the house was made from her sweat, everyday working so hard, washing people clothes. She never and ever leaves her home.

Delia is a religious person. She often goes to the church. When something happened to her, God is the place she is asking for help. Before she sleeps, she is praying.

Oh well, whatever goes over the Devil's back, is got to come under his belly. Sometime or ruther, Sykes, like everybody else, is gointer reap his sowing. (Sweat:1024)

It means, Sykes will get the consequences from what he did. She believed someday he will pay whatever he did, and God knows it. According to Sociology of Religion, praying may lead to reduced exposure to stressful events and conditions, such as marital and family conflicts, economic and legal problems, and others. (2014:210)

In the middle of the night, when she was sleeping, Sykes' coming and laying beside her, suddenly he asked her to give him the cover. But he asked in abusive way.

She went to sleep and slept until he announced his presence in bed by kicking her feet and rudely snatching the covers away.

'Gimme some kivah heah, an' gityo' damn foots over on yo' own side! Ah oughter mash you in yo' mouf fuh drawing dat skillet on me"

Delia went

clear to the rail without answering him. (Sweat:1024)

Based on the citation above, Sykes is so dominant. He thinks everything will be submissive if he is asking roughly. Then Delia gives him the cover without answering him. It seems she is tired of quarrel.

Delia will not leave home. There is final way to chase her away. Sykes brings her a real snake. A rattle snake. He puts it inside the box, and put it at home. He think, with real snake, she can't stay at home, even she will not take closer at her house.

Look in de box dere Delia, Ah done brung yuh somethin'!

Syke! Syke, mah Gawd! You take dat rattlesnake 'way from heah! You gottuh. Oh, Jesus, have mussy!

Ah aint gut tuh do nuthin' uh de kin'--fact is Ah aint got tuh do nothin' but die. Taint no use uh you putting' on airs makin' out lak you skeered uh dat snake-he's gointer stay right heah tell he die. He wouldn't bite me cause Ah knows how tuh handle 'im. Nohow he wouldn't risk breakin' out his fangs 'gin yo' skinny laigs. (Sweat:1026) After he bring Delia the real snake, they got conflict. Sykes gives her verbal abuse. He insults her physically.

Well, Ah'm glad you does hate me. Ah'msho' tiahed uh you hangin' ontuh me. Ah don't want yuh. Look at yuhstringey ole neck! Yo' rawbonylaigs an' arms is enough 
tuh cut uh man tuh death. You looks jes' lak de devvul's doll baby tuh me. You cain't

hate me no worse dan Ah hates you. Ah been hatin' you fuh years. (Sweat:1027)

Based on the citation above, it seems he achieved his goals to make his wife hates him. It can be seen in the citation "Ah'm glad you does hate me". There is satisfying inside him while doing some violence to his wife.

Those are how domestic violence and man domination happens in Sweat. Kinds of verbal violence, psychological violence, physical violence are used.

\section{What are the effects of man domination and domestic violence toward woman in Zora's Sweat ?}

In this chapter, the researcher will analyze the effect of man domination and domestic violence in Sweat. The way Sykes dominates is making Delia keep in submissive position by giving her fear, terror, and misery. With fear, Sykes using snakes to scare her. With terror, he has girlfriend and he swears to live in the house, and chases Delia away. With misery, she has to work for life. She works for years, and Sykes didn't do anything. That is how Sykes treats her to live in misery. Sykes doesn't have a job, so the impact is, his wife has to work for survive. She has to work by washing people clothes for fifteen years.

Looka heah, Sykes, you done gone too fur. Ah been married to you fur fifteen years, and Ah been takin' in washin fur fifteen years. Sweat, sweat, sweat! Work and sweat, cry and sweat, pray and sweat! (Sweat:1023)

Research and specialized practice indicate that women who are abused by their intimate partners are at an increasing risk the longer the abuse continues. Slabbert, Ilze and Silvana Green (2013:234). It is hard to her, spending day by day in hard situations, working, and has abusive husband. She used to be beautiful before she had married. Delia became thin after she got violence. She depressed. Hamberger, Saunders \& Hovey said, Thousands of these victims struggle with the health consequences of being trapped in abusive relationships without being identified by health care providers or provided with proper treatment (1992 : 283-287). This is the effect of violence. In the citation below, the dialog is from Walter Thomas, their neighbor, showing the evidence she was beautiful before she married.

But even so, he useter eat some mighty big hunks uh humble pie tuh git dat lil' 'oman he got. She wuz pretty ez a speckled pup! Dat wuz fifteen yeahs ago. He useter be so skeered uh losin' huh, she could make him do some parts of a husband's duty. Dey never wuz de same in de mind. (Sweat:1024)

In the citation above it can be proven she was beautiful "She wuz pretty ez a speckled pup! Dat wuz fifteen yeahs ago". According to World Health Organization, exposure to violence leads to poorer physical health overall compared with women who have not experienced

MAN DOMINATION AND DOMESTIK VIOLENCE DESCRIBED IN SWEAT BY ZORA NEALE HURSTON - YOGI ARIO SETIAWAN \& AGNES WIDYANINGRUM - DBB V15 N1 JANUARI 2020 
violence and it increases the risk of women developing a range of health problems. Delia has the healthy problem it is shown by her skinny body. That is the effect of domestic violence.

Another effect is people in the village also hates him, because they knew, Sykes is abusive husband. When people having chit chat, suddenly Sykes is coming with his girlfriend, then people around left.

Most of the men left also. Just then Delia drove past on her way home, as Sykes was ordering magnificently for Bertha. It pleased him for Delia to see. (Sweat 1025)

People hates him too. He is disrespect to his wife according to citation above "Just then Delia drove past on her way home, as Sykes was ordering magnificently for Bertha. It pleased him for Delia to see". It seems he wants to show off, and makes his wife hates him, and cannot stay with him.

Delia got trauma because of violence. She secludes to avoid the society. The citation below shows Delia becomes loner.

She avoided the villagers and meeting places in her efforts to be blind and deaf. (Sweat 1026)

Because she got violence for almost every day, she just feels giving up to him. No more hopes. It can be seen in the citation below.

Ah hates you Sykes, Ah hates you tuh de same degree dat A useter love yuh. Ah done took an' took till mah belly is full up tuhmah neck. Dat's de reason Ah got mah letter fum de church an' moved mah membership tuh Woodbridge-so Ah don't haftuh take no sacrament widyuh. Ah don't wantuhseeyuh 'roun' me atall. Lay 'roun' widdat 'oman all yuh wants tuh, but gwan 'way fum me an' mah house. Ah hates yuhlak uh suck-egg dog.

And the last decision, she hates him. She really did not care anymore. Delia does not want to know, and to help his husband from the snake bite, even her husband shout at her asking for help. But she did not do anything. It is the expression of her to show that she hates him.

The sun was growing warm. As she approached the door she heard him call out hopefully.

Delia, is dat you Ah heah?

She saw him on his hands and knees as soon as she reached the door. He crept an inch or two toward her---all that he was able, and she saw his horribly swollen neck and his one open eye shining with hope. (Sweat:1030)

Based on this analysis it can be concluded that Delia, suffered from trauma and stress, which made her body thin, because she was physically and psychologically abused for almost fifteen years. 


\section{CONCLUSION}

The purpose of this study is to look back that in a patriarchal society, men tend still to dominate in terms of marriage relations. And many women still get oppressive actions in the marriage relationship.

In Sweat, Sykes has an abusive character. He often acts rude towards his wife, Delia, with the aim of making her leave the house, so Sykes and his girlfriend can live together. Delia is not losing her house easily. She remained in the house. She spends her daily life working and praying. Hoping there will be a miracle that can change her life becomes better. Delia persisted because she felt the house was the result of her hard work. She persisted even though her husband always acted harshly.

Sykes has a taste for girls who have fat bodies. His girlfriend has these advantages. Which made Sykes falls in love with her. In contrast to Delia, she had no fat bodies, which probably made Sykes dislike her. Harsh words that said Delia's thinness often came out of Sykes's mouth.

Delia's work as a washer for white people clothes also made Sykes act harshly towards her. Delia has no other choices, she must take the work to provide their life, because her husband does not have job.

The occupation of the house, the wife who is not look exciting, and the wife's job washing clothes for white people, are some of the reasons why man domination and domestic violence occur in Sweat.

This short story illustrates several forms of violence that occurred ranging from physical violence, or psychological violence. Sykes in Sweat, terrorizes his wife by throwing bull whips. His wife who thought the item was a snake, felt shocked and scared. Deliberately frightening Delia like that, Sykes hoped that his wife would not like it, and left home.

Sykes disagreed with what Delia was doing as a laundry for white people. Once when Delia was doing her work, Sykes kicked off the clothes she was doing. This he did to show his dominance in domestic life.

After experiencing some violent behavior from her husband, of course there will be an impact on Delia. She had to work by washing clothes, for fifteen years. This happened because her husband did not work.

Another impact caused by the violence committed by her husband is, Delia's body becomes thin. This can occur because of stress and depression, which makes Delia has no good health. He also became a loner. 
Delia became indifferent to her husband. She felt she had suffered a lot of physical and psychological violence, which made her hate and not care about her husband, even though Delia saw and heard her husband asking for help because of being bitten by a snake, Delia decided to be quiet and let him die.

Zora Neale Hurston in the novel Sweat, is trying to describe how women are still treated arbitrarily. She is made to obedient, and she has no right to say anything. Sweat represents the lives of women trapped in bad marriage life.

\section{REFERENCES}

Beauvoir, Simone de. 2011. The Second Sex. New York: Vintage Books.

Dery, Isaac and Diedong, Africanus L. 2014. Domestic Violence against Women in Ghana: An Exploratory Study in Upper West Region, Ghana.

Ellison, Christopher G. 2014. Sociology of Religion _ _ : Oxford University Press.

Freedman, Jane. 2001. Feminism (Concepts in the Social Sciences).

H.G. Tarigan. 1993. Berbicara sebagai suatu Keterampilan Berbahasa. Bandung : Angkasa Badudu.

Hamberger, L. K., Saunders, D. G., \& Hovey, M. 1992. Prevalence of domestic violence in community practice and rate of physician inquiry.

Klarer, Mario. 2005. An Introduction to Literary Studies. Oxfordshire: Taylor \& Francis eLibrary.

Lorber, Judith. 1997. The Variety of Feminisms and their Contributions to Gender Equality. : Universität Oldenburg

M. H. Abrams. 1999. A Glossary of Literary Terms ( $7^{\text {th }}$ ed.). Massachusetts: Earl McPeek.

Meyer, Jim. 1997. What is Literature? A Definition Based on Prototypes. Mattapan :

Nurgiantoro, Burhan. 2002. Teori Pengkajian Fiksi. Fourth edition. Yogyakarta: Gajah Mada University Press.

Ollila, Bernie and Jantas, Joe. 2006. The Definition of Poetry.__:

PFVB1100-men-abused-by-women-booklet.pdf.

Slabbert, Ilze and Silvana Green. 2013. Types of Domestic Violence Experienced by Women in Abusive Relationships.____types_of_characters_in_fiction.pdf 
Warshaw, Carole M.D \& Ganley, Anne L, Ph.D. 1996. IMPROVING THE HEALTH CARE RESPONSE TO DOMESTIC VIOLENCE: A RESOURCE MANUAL FOR HEALTH CARE PROVIDERS ( $2^{\text {nd }} e d$.).

William Boyd History Short Story.pdf

World Health Organization. 2013. Global and Regional Estimates of Violence Against Women: prevalence and health effects of intimate partner violence and non-partner sexual violence. Geneva: WHO Press.

_. 2009. A Guide to the Study of Literature: A Companion Text for Core Studies 6, Landmarks of Literature [electronic resource] English Department, Brooklyn College, New York.

_. 2010. The National Intimate Partner and Sexual Violence Survey, Summary Report.

https://acesdv.org/domestic-violence-graphics/

http://www.k12reader.com/term/prosel

https://www.biography.com/scholar/simone-de-beauvoir

https://www.gradesaver.com/sweat/study-guide/summary

https://www.britannica.com/biography/Zora-Neale-Hurston

https://www.lexico.com/en/definition/setting 